\title{
PRAWO AUTORSKIE W POLSCE W DOBIE SPOLECZEŃSTWA INFORMACYJNEGO - GŁOS KRYTYCZNY UŻYTKOWNIKÓW PRAW
}

\section{WPROWADZENIE}

Zamierzeniem autora niniejszego artykułu jest przedstawienie w debacie toczącej się z okazji dwudziestolecia wejścia w życie ustawy o prawie autorskim i prawach pokrewnych z 4 lutego 1994 r. ${ }^{1}$ punktu widzenia użytkowników praw wyłącznych. Jest to uzasadnione pomijaniem interesów tej grupy $\mathrm{w}$ dotychczasowej dyskusji, mimo jej fundamentalnego znaczenia dla całego systemu prawa autorskiego. Większość wypowiedzi doktryny, a także działań podejmowanych przez stosowne organy państwowe oraz międzynarodowe skupia się przede wszystkim na przeciwdziałaniu i zwalczaniu naruszeń praw wyłącznych, czego przykładem może być chociażby działający pod przewodnictwem Ministra Kultury i Dziedzictwa Narodowego (MKiDN) Zespół do spraw Przeciwdziałania Naruszeniom Prawa Autorskiego i Praw Pokrewnych. Już sama nazwa tego zespołu determinuje jego cele i zakres powierzonych mu zadań. Zapomina się zatem, że wspieranie twórczości i ochrona praw autorów i podmiotów praw pokrewnych ma znaczenie i sens tylko wtedy, gdy powstałe dobra niematerialne przyczyniają się do rozwoju społeczeństwa oraz kultury. Aby to jednak nastapiło, wynik pracy twórczej musi znaleźć swych odbiorców.

W konsekwencji uznać należy, że odbiorca twórczości jest podmiotem równie istotnym jak sam autor. System prawny nie ma bowiem na celu wyłącznie ochrony praw jednostki, która w swym partykularnym interesie ma uzyskiwać konkretne korzyści, zazwyczaj natury majątkowej. Wprowadzane regulacje prawne zmierzać powinny do zapewnienia równowagi między nierzadko spornymi interesami twórcy oraz odbiorcy kultury, czyli „tego, kto w ustawie nie jest wymieniony, ale kto decyduje o sensie całego skomplikowanego systemu powiązań [...]. Ten milczacy podmiot ustawy o prawie autorskim i prawach pokrewnych to oczywiście odbiorca twórczości czytelnik, słuchacz, widz, który w ostatecznym rachunku również finansuje cała tą działalność [...]. I to dla tego właśnie podmiotu, dla odbiorcy, w gruncie rzeczy musi być ta ustawa" (wyróż. - J.S.)².

\footnotetext{
1 T.jedn.: z 17 maja 2006 r., Dz. U. Nr 90, poz. 631 ze zm. (dalej jako: pr.aut.).

${ }^{2}$ Sprawozdanie Komisji Kultury i Środków Przekazu oraz Komisji Ustawodawczej o pilnym rządowym projekcie ustawy o prawie autorskim i prawach pokrewnych (Druk nr 86 i 198). 2 kadencja, 9 posiedzenie, 1 dzień (5 stycznia 1994 r.).
} 
Obecnie retoryka stosowana $\mathrm{w}$ kontekście praw autorskich nierzadko przyjmuje analogiczne brzmienie do dyskursu dotyczącego prawa karnego, które według niektórych środowisk należy wciąż zaostrzać, aby osiagać cele stawiane tej dziedzinie prawa. Założenie takie jest błędne. Prawidłowo funkcjonujące mechanizmy systemu prawa autorskiego dawałyby bowiem o wiele lepsze efekty niż zwiększanie jego represyjności, szczególnie wobec faktycznej niemożliwości wyegzekwowania wielu norm. Dodatkowo pamiętać należy, że w dobie społeczeństwa informacyjnego i ciagłego rozwoju nowych sposobów eksploatacji utworów, ale także i procesów ich powstawania coraz bardziej zacierają się granice między twórcą a odbiorcą. Dlatego też niezbędne jest otwarcie dyskusji publicznej na argumenty wszystkich zainteresowanych stron oraz podjęcie prac nad ukształtowaniem systemu prawa autorskiego w taki sposób, aby zaspokajał on potrzeby całego społeczeństwa i przyczyniał się do dalszego rozwoju kultury.

Konieczność wprowadzenia zmian w istniejącym obecnie na podstawie ustawy systemie ochrony prawnoautorskiej dostrzegaja nie tylko aktywni użytkownicy praw autorskich i praw pokrewnych, lecz także coraz częściej przedstawiciele władzy wykonawczej, judykatury oraz doktryny prawa. Aktualny stan funkcjonowania prawa autorskiego w Polsce jest bowiem krytyczny. Ustawa weszła w życie, co do większości zawartych w niej norm, 24 maja 1994 r. Od tej daty poddano ją ponad piętnastu nowelizacjom. O ile część wprowadzonych zmian można nazwać kosmetycznymi, o tyle kilka zdecydowanie rewolucjonizowało jednak system prawa autorskiego i ochrony prawnoautorskiej. Mimo to powszechnie uważa się, że mamy dzisiaj do czynienia z impasem, który często uniemożliwia prawidłowe funkcjonowanie prawa autorskiego w Polsce. Z punktu widzenia rynku medialnego i jego użytkowników jedną z najistotniejszych zmian było bez wątpienia wprowadzenie do ustawy pojęcia „reemisja”, a także zaadaptowanie jej treści do znamiennego wyroku Trybunału Konstytucyjnego z 24 stycznia 2006 r. (SK 40/04), który dotyczył przede wszystkim procedury zatwierdzania tabel wynagrodzeń oraz zasad funkcjonowania Komisji Prawa Autorskiego. Trybunał uznał, że kwestionowany przez skarżąca spółkę przepis art. 108 ust. $3 \mathrm{w}$ związku z art. 109 ustawy jest niezgodny z art. 20 , art. $22 \mathrm{w}$ związku z art. 31 ust. 3 , art. 45 ust. 1 i art. 77 ust. 2 Konstytucji RP w zakresie, w jakim wyłącznym projektodawca tabel wynagrodzeń za korzystanie z utworów i artystycznych wykonań czyni organizacje zbiorowego zarządzania prawami autorskimi lub prawami pokrewnymi (OZZ), wykluczając z procesu ich kształtowania przedstawicieli użytkowników. Taki stan rzeczy Trybunał słusznie uznał za przekraczajacy konstytucyjna zasadę proporcjonalności. Eliminacja roli użytkowników stwarzała, co odnotował Trybunał, poważne zagrożenie dla prawidłowej i obiektywnej oceny przez organ zatwierdzanej tabeli wynagrodzeń. Kwestionowany przepis został uznany ze niezgodny z Konstytucją RP także dlatego, że uniemożliwiał użytkownikom prawidłowe przedstawienie równoprawnego stanowiska w trakcie postępowania w sprawie zatwierdzania tabel. W konsekwencji zakwestionowana regulacja uniemożliwiała zapewnienie pełnej ochrony w trakcie kontroli 
sądowoadministracyjnej rozstrzygnięcia w przedmiocie zatwierdzenia tabel wynagrodzeń.

Wspomniany wyroku Trybunału stanowi egzemplifikację koniecznej interwencji w zakresie dysproporcji funkcjonujących pomiędzy użytkownikami praw chronionych ustawa a twórcami i podmiotami praw pokrewnych. Niestety pomimo eliminacji z systemu prawnego wspomnianego przepisu problematyka braku równowagi w prawie autorskim nadal stanowi najbardziej palący problem, przed którym stoi obecnie zarówno polskie ustawodawstwo, jak i praktyka stosowania prawa.

Oprócz oczywistych i licznych braków legislacyjnych kolejnym wyzwaniem stojącym przed ustawodawcą jest postępujący rozwój technologiczny. Rosnaccy rynek usług Video-on-demand (VoD) rozwój usług bazujących na user-generated-content czy kwestia reemisji realizowanej za pośrednictwem różnych technologii stanowią wyłącznie wycinek omawianej problematyki, lecz mimo to nadal nie doczekały się one kompleksowej regulacji ustawowej, która gwarantowałaby pewność i przejrzystość obrotu, dogodny dla społeczeństwa dostęp do utworów oraz odpowiednie wynagrodzenie dla ich twórców. Podjęte dotychczas działania nowelizacyjne nie zaspokajały wszystkich naglacych potrzeb rynku, a wielokrotnie podkreślana przez Komisję Europejska zasada neutralności technologicznej, jako jedna z nadrzędnych norm regulacji sektorowych, nie znalazła do dzisiaj pełnego odzwierciedlenia w przepisach ustawy.

Konieczne jest zatem wprowadzenie zmian w systemie prawa autorskiego, które w sposób kompleksowy dostosowałyby go do potrzeb współczesności i wszystkich zainteresowanych. Obecny status quo, którego główne aspekty zostana zaprezentowane w niniejszym artykule, jest nie do zaakceptowania z uwagi na szereg problemów generowanych zarówno dla użytkowników, jak i samych twórców, skutkujących niewydolnością prawa autorskiego. Bezpośrednim impulsem i przyczyną mającą zdecydowanie największy wpływ na zakres niniejszego artykułu jest brak niezbędnych działań ze strony MKiDN. Zarzut ten nie dotyczy jednak tylko ustawy, lecz także chaosu i licznych błędów w wydanych w ciagu ostatnich dwudziestu lat zezwoleniach na rzecz OZZ oraz braku należytego nadzoru nad tymi podmiotami ze strony MKiDN. Obecny chaos w tym zakresie stanowi przyczynę wielu dalszych komplikacji, które z powodu niezbędnych zmian mogą być usunięte tylko na drodze gruntownej nowelizacji ustawy, poprzedzonej szeroką debatą publiczną i niezbędnymi analizami oraz badaniami.

\section{OPIS PROBLEMÓW}

\section{Archaizm ustawy i brak realizacji zasady neutralności technologicznej}

Źródłem obecnej kondycji prawa autorskiego w Polsce jest w dużej mierze brak niezbędnych działań legislacyjnych umożliwiających dostosowanie przepisów ustawy do szybkich zmian technologicznych dotyczących przede wszystkim sposobu korzystania z utworów i przedmiotów praw pokrewnych. Nowe 
technologie oraz sposoby eksploatacji dóbr niematerialnych, takie jak wspominane VoD, reemisja w sieciach satelitarnych, ekspansja naziemnej telewizji cyfrowej, upowszechnianie mobilnego Internetu, digitalizacja dorobku kulturowego czy tzw. Internet rzeczy, bezsprzecznie wpływają na powstanie nowych pól eksploatacji wymykających się regulacjom ustawowym. Próby wtłaczania nowo powstających pól eksploatacji i zmieniającej się rzeczywistości oraz stanu technologicznego w obecne ramy legislacyjne stanowia niewystarczajace rozwiązania praktyki, które w dłuższej perspektywie nie usuwają istniejących problemów, a jedynie je tymczasowo maskują.

Szczególnie widocznym problemem jest brak definicji legalnej utworu audiowizualnego. Stan taki prowadzi do niezwykle negatywnych skutków, gdyż każda grupa interesów dokonuje własnej interpretacji tego pojęcia w sposób jak najbardziej dogodny dla siebie. Prowadzi to do licznych sporów doktrynalnych oraz sądowych, które jednak nadal nie dają jednoznacznej odpowiedzi na wątpliwości dotyczące zakresu podmiotowego uprawnionych do stosownego wynagrodzenia z tytułu eksploatacji utworu audiowizualnego. Niektóre OZZ, które posiadają znacznie silniejsza, a nierzadko wręcz dominująca, pozycję rynkową w stosunku do użytkowników, próbują narzucić im obowiązek de facto podwójnego uiszczania wynagrodzenia autorskiego za korzystanie w istocie $\mathrm{z}$ tego samego dobra niematerialnego. Organizacje te bowiem stoja na stanowisku, wedle którego eksploatacja jednolitych przecież i mających bezsprzecznie indywidualne znaczenie utworów audiowizualnych wiąże się z jednoczesnym i równoległym korzystaniem z tzw. utworów wkładowych. Jednocześnie MKiDN, wydajac zezwolenia na wykonywanie zbiorowego zarządu (dotyczy to w szczególności Stowarzyszenia Autorów ZAiKS), bez jakiejkolwiek podstawy w przepisach ustawy udzielił zezwolenia na zbiorowe zarządzanie tzw. małymi prawami w utworach audiowizualnych ${ }^{3}$. W konsekwencji decyzja administracyjna, która nie jest źródłem prawa powszechnie obowiązującego, stanowi często argument majacy zadecydować o konstrukcji jurydycznej pojęcia ustawowego, lecz niezdefiniowanego, jakim jest utwór audiowizualny. Jest to stan o tyle trudny dla użytkowników, że orzecznictwu sądów powszechnych oraz Sądu Najwyższego, które w przeważającej mierze opowiada się za jednolitą koncepcją utworu audiowizualnego, przedstawia się wspomnianą decyzję MKiDN. W uchwale Sądu Najwyższego z 25 listopada 2008 r. (III CZP 57/08) wskazano, że: „utwór audiowizualny jest jednym utworem, a nie zbiorem różnych utworów tzw. wkładowych [...]. Z tego, że utwór audiowizualny stanowi jedną całość, wynika, że jego eksploatacja nie wymaga dodatkowych licencji dotyczących jego integralnych części” (wyróż. - J.S.). Podobne stanowisko wyraził chociażby Sąd Apelacyjny w Warszawie w wyroku z 7 lutego 2014 r. (I ACa 452/13) oraz w wyroku z 7 maja 2014 r. (I ACa 1663/2013). W drugim z wymienionych orzeczeń stwierdzono, że „nie można tak rozumieć art. 70 uopapp, że do utworów będących częściami składowymi utworu audiowizualnego powstaja niejako dwa zestawy praw autorskich - do

${ }^{3}$ Zob. http://www.prawoautorskie.gov.pl/media/zbiorowy_zarzad/obwieszczenie_26032009_ prawoautor.pdf. Decyzja DP.041/Z/8/95 z 1 lutego 1995 r., zmieniona ostatnio decyzją DP.WPA. 024/98/03/mp z 28 lutego 2003 r. 
utworu będącego częścią składową utworu audiowizualnego i tego samego utworu jako utworu samodzielnego. W konsekwencji, wykorzystanie całości utworu audiowizualnego nie stanowi naruszenia prawa przysługującego twórcy do części składowej”.

Powyższe prowadzi do konstatacji, że wprowadzenie do treści ustawy definicji legalnej utworu audiowizualnego jest najlepszym posunięciem umożliwiającym eliminację stanu niepewności i sporów interpretacyjnych, za które ów brak odpowiada.

Kolejna kwestia jest problematyka nieprzestrzegania przez polskiego ustawodawcę zasady neutralności technologicznej, co dodatkowo pogłębia postępujacy stan dezaktualizacji ustawy. Wspomniana zasada na podstawie obiektywnych kryteriów determinuje tworzenie warunków do uczciwej konkurencji i rozwoju technologicznego, zakładając zakaz dyskryminowania lub wspierania konkretnych rozwiązań bądź standardów technologicznych. Znajdując zastosowanie również na gruncie innych aktów prawnych, jak chociażby w ustawie Prawo telekomunikacyjne ${ }^{4}$, zasada ta stanowi obecnie jedna z podstaw unijnych regulacji sektorowych, jako wyznacznik działań właściwych organów administracji. Najlepszym przykładem nieprzestrzegania zasady neutralności technologicznej na gruncie systemu prawa autorskiego w Polsce jest niedostosowanie ustawy do wspomnianych powyżej nowoczesnych form eksploatacji utworów, w tym w szczególności za pośrednictwem Internetu. Ów archaizm niektórych norm prawa autorskiego, które wprost odnoszą się do konkretnych rozwiązań technologicznych, odstaje od rzeczywistości z pokrzywdzeniem dla niektórych grup użytkowników. Przykładem takiej sytuacji są normy dotycząca reemisji, która w praktyce może być i z powodzeniem w praktyce jest dokonywana dowolna technika ${ }^{5}$. Ustawodawca, powielając terminologię dyrektywy Rady 93/83/EWG z 27 września 1993 r. w sprawie koordynacji niektórych zasad dotyczacych prawa autorskiego oraz praw pokrewnych stosowanych $\mathrm{w}$ odniesieniu do przekazu satelitarnego oraz retransmisji droga kablowa ${ }^{6}$, ukształtował brzmienie ustawy w sposób narzucający określone obowiązi wyłącznie na operatorów sieci kablowych. Dotyczy to w szczególności nieprawidłowo implementowanego w Polsce obowiązkowego zastępstwa kontraktowego OZZ (art. 9 dyrektywy satelitarno-kablowej), wdrożonego w art. $21^{1}$ ust. 1 ustawy. Stan taki uprzywilejowuje inne kategorie reemitentów, jak chociażby platformy satelitarne.

\section{Brak niezbędnych działań MKiDN}

Bez wątpienia obecnie obowiązująca ustawa w dużej mierze nie przystaje do realiów ekonomiczno-technologicznych, w których cyfrowa eksploatacja ma rosnące znaczenie. W'śród przyczyn takiego stanu rzeczy upatrywać na-

${ }^{4}$ Art. 189 ust. 2 pkt 5 ustawy z 16 lipca 2004 r. - Prawo telekomunikacyjne, t.jedn.: Dz. U. 2014, poz. 243 ze zm.

${ }_{5}^{5}$ Za pośrednictwem sieci kablowych, przekazu satelitarnego, bądź naziemnego, czy w Internecie.

${ }^{6}$ Dz. Urz. UE L 248 z 6 października 1993 r. (dalej jako: dyrektywa satelitarno-kablowa). 
leży m.in. w licznych zaniechaniach MKiDN, który jako organ administracji kształtujący krajową politykę dotyczącą praw autorskich i pokrewnych odpowiada za wszelkie problemy występujace w tej domenie. Organ ten powinien na bieżąco prowadzić stosowne badania i analizy dotyczące efektywności prawa autorskiego oraz diagnozować występujące nadużycia. Działania takie były jednak przez wiele lat zaniedbywane, co w efekcie doprowadziło do obecnego i powszechnie krytykowanego stanu ustawy, jej postępujacej archaizacji oraz licznych wad, które skutkują brakiem odpowiedniej efektywności istniejących instrumentów prawnych.

Jedną z najbardziej dotkliwych dla użytkowników wad ustawy jest całkowicie nieskuteczny system uzyskiwania licencji na korzystanie z praw zarządzanych przez OZZ. Objawia się to nader częstym brakiem realizacji przez te organizacje ustawowego obowiązku udzielania zgody na korzystanie z utworów, wyrażonego w art. 106 ust. 3 ustawy. Spowodowane jest to przede wszystkim brakiem jakiejkolwiek, nawet iluzorycznej, sankcji wobec OZZ z tytułu braku realizacji przedmiotowego obowiązku. Stan ten jest szczególnie dotkliwy w przypadkach występowania obowiązkowego zastępstwa kontraktowego OZZ, kiedy to użytkownicy nie maja prawnej alternatywny zawarcia umowy bezpośrednio z uprawnionymi. Przykładem takiej sytuacji jest istniejący od ponad 5 lat spór między Stowarzyszeniem Filmowców Polskich a branżą operatorów sieci kablowych, który dotyczy wysokości należnej wspomnianej organizacji stawki wynagrodzenia. Stowarzyszenie to, mimo wielu propozycji rozwiązań tymczasowych, odmawia operatorom udzielenia zgody na dokonywanie reemisji w sieciach kablowych w sytuacji, gdy ci nie zaakceptuja stawki wynagrodzenia żądanej przez OZZ. Działanie takie jest oczywiście bezprawne. Przepis art. 106 ust. 3 ustawy daje bowiem OZZ możliwość odmowy zawarcia umowy zezwalającej na korzystanie z utworów lub przedmiotów praw pokrewnych wyłącznie w przypadku wystapienia „ważnych powodów”. Sądy powszechne wraz z Sądem Najwyższym wielokrotnie wskazywały, że rozbieżność stanowisk stron negocjującej umowę licencyjną wyłącznie w zakresie wysokości stawki wynagrodzenia, z którą to sytuacją bez wątpienia mieliśmy i mamy do czynienia w przedstawionym stanie faktycznym, ,jest sporem o treść (warunki) tej umowy, a nie sporem co do nieistnienia obowiązku zawarcia umowy z ważnych powodów, o których mowa w art. 106 ust. 2 u.p.a.p.p.”’

Podnieść należy, że wspomniany już brak sankcji z tytułu naruszania wskazanego obowiązku jest jednocześnie przykładem braku skutecznej harmonizacji prawa polskiego z regulacjami unijnymi. Artykuł 12 dyrektywy satelitarno-kablowej zobowiązuje bowiem państwa członkowskie do wdrożenia norm, które gwarantowałyby przystapienie w dobrej wierze przez OZZ i użytkowników do negocjacji oraz ich prowadzenie również w dobrej wierze. Polski ustawodawca, mimo upływu niemalże 11 lat od terminu implementacji dyrektywy satelitarno-kablowej, do dzisiaj nie wprowadził niezbędnych regulacji prawnych. Rozwiązaniem tej problematyki mogłoby być prawidłowo funkcjonujące postępowanie mediacyjne prowadzone przed Komisją Prawa Autor-

${ }^{7}$ Wyrok SN z 12 stycznia 2012 r., IV CSK 200/11, Lex, nr 1135997. Zob. też: wyrok SN z 8 lipca 2011 r., IV CSK 638/10, Lex, nr 1001333. 
skiego. W obecnym brzmieniu art. $110^{18}$ ustawy postępowanie to jest jednak rozwiązaniem czysto iluzorycznym. Pełniąc od wielu lat funkcję prezesa zarządu Polskiej Izby Komunikacji Elektronicznej, która zrzesza duże grono użytkowników zainteresowanych efektywnym negocjowaniem z uprawnionymi z tytułu praw autorskich i pokrewnych, mam możliwość obserwacji praktyki stosowania przepisów ustawy. Od wprowadzenia w 2010 r. nowelizacji przepisów ustawy dotyczących m.in. postępowania mediacyjnego, zgodnie z moja wiedza, wszczęte zostały tylko trzy takie sprawy. Wszystkie te postępowania, ze względu na ich dobrowolność, zakończyły się jednak fiaskiem spowodowanym odmową udziału OZZ. Opisany status quo prowadzi do sytuacji, w których OZZ działające częstokroć w realiach rzeczywistego monopolu mogą bezkarnie odmawiać z nieuzasadnionych przyczyn zawierania umów licencyjnych (do czego zostały notabene powołane), próbując jednostronnie dyktować warunki i nadużywając tym samym swojej dominującej pozycji rynkowej. Użytkownicy sa bezradni wobec takich nierynkowych praktyk, co skutecznie uniemożliwia wielu podmiotom prowadzenie działalności gospodarczej, ze szkodą dla użytkownika końcowego - odbiorcy kultury.

Niewłaściwie sprawowany przez MKiDN nadzór nad OZZ wobec nadużyć prawa dokonywanych przez wskazane organizacje paraliżuje obrót prawami autorskimi i pokrewnymi. Organizacje te wykorzystują bowiem instrumentalnie roszczenia prawnoautorskie do jednostronnego kształtowania relacji umownych z użytkownikami, narzucając im wysokość stawek wynagrodzenia. Dwie największe w Polsce organizacje zbiorowego zarządzania podejmują liczne działania zmierzające do opóźnienia zatwierdzenia tabel wynagrodzeń, nie wywiązując się tym samym kolejny raz ze swoich ustawowych obowiązków.

Ponad cztery lata od wejścia w życie 21 października 2010 r. nowelizacji ustawy mającej wypełnić lukę istniejącą w polskim prawie autorskim po wspominanym wyroku Trybunału Konstytucyjnego w sprawie SK 40/04 i obowiązywania rozbudowanych przepisów dotyczących chociażby Komisji Prawa Autorskiego stwierdzić niestety należy, że aktualne nadal pozostają wszelkie zastrzeżenia zgłaszane wielokrotnie przez licznych uczestników konsultacji społecznych w toku procesu legislacyjnego, a zignorowane wówczas przez ustawodawcę. Upływ czasu boleśnie obnażył szereg wad stworzonego systemu funkcjonowania Komisji Prawa Autorskiego. Organ ten nie wypełnia bowiem swojej podstawowej roli merytorycznej i specjalistycznej oceny tabel wynagrodzeń oraz rozstrzygania sporów między OZZ i użytkownikami.

Mimo wielokrotnych apeli podmiotów reprezentujących interesy użytkowników, uprawnionych oraz przedstawicieli doktryny wciąż nie podejmuje się prac nad niezbędnymi zmianami. Jednocześnie procesy legislacyjne, nawet dotyczące zmian pojedynczych przepisów (jak obecnie przygotowywany projekt zmiany art. $21^{1}$ ustawy) trwaja nawet po kilka lat. Praktyka ostatnich kilku lat prowadzi do przykrej konstatacji, że projekty nowelizacyjne przygotowywane są często dopiero w reakcji na zdecydowane działania Komisji Europejskiej, która grozi Polsce sankcjami za nieterminowe lub niewłaściwe implementowanie prawa unijnego. Przykładem tego jest wspomniana powyżej nowelizacja art. $21^{1}$ ustawy, która jest skutkiem działań Komisji Europejskiej wobec skargi PIKE z grudnia 2011 r. Bierność w kwestii zmian systemu pra- 
wa autorskiego jest o tyle zaskakująca, że współcześnie podkreśla się ważkość i potencjał rynku praw autorskich i dziedzin pokrewnych w rosnacym społeczeństwie informacyjnym. Wyzwania współczesności oraz oczekiwania społeczno-rynkowe wymagaja szybkich, zdecydowanych zmian prawnych opracowanych przez specjalistów w swojej dziedzinie, które zapewniałyby aktualność omawianej regulacji.

Postulat zmian w działaniu MKiDN jest tym istotniejszy, że wszelkie zaniedbania w tym zakresie prowadzą do licznych naruszeń konstytucyjnej zasady równości, która wyraża się w kompromisie pomiędzy interesami nie tylko różnych podmiotów uprawnionych twórców, producentów, artystów wykonawców, ale również interesami użytkowników.

\section{Represyjność roszczeń prawnoautorskich}

Rozległym tematem, który w pełni zasługuje na odrębną pracę zawierająca pogłębioną analizę porównawczą oraz dogmatyczną, jest problematyka roszczeń prawnoautorskich, określonych w art. 79 ust. 1 ustawy. Aktualna konstrukcja odpowiedzialności odszkodowawczej w ustawie sprowadza się bowiem do kary cywilnej, a nie obiektywnej rekompensaty. W istocie bowiem art. 79 ust. 1 pkt 3 lit. b ustawy zawiera bodajże pierwszy w historii polskiego ustawodawstwa przykład instrumentu powszechnie stosowanego w systemach anglosaskich, to jest odpowiedzialności punitive damages. Przepis ten przewiduje bowiem możliwość dochodzenia przez uprawnionego trzykrotności stosownego wynagrodzenia, które byłoby należne tytułem udzielenia zgody na korzystanie z utworu w oderwaniu od wysokości szkody, czy nawet jej faktycznego zaistnienia. Problematyka ta stanowi obecnie przedmiot skargi konstytucyjnej jednego z operatorów telewizji kablowej, która rozpatrywana jest przez Trybunał Konstytucyjny pod sygnatura akt SK 32/14. Rzecznik Praw Obywatelskich w swojej opinii z 20 listopada 2014 r. dotyczącej przedmiotowej skargi stanął na stanowisku, że art. 79 ust. 1 pkt 3 lit. b ustawy w zakresie, w jakim nakłada obowiązek zapłaty trzykrotności stosownego wynagrodzenia na rzecz podmiotu uprawnionego z tytułu naruszenia autorskich praw majatkowych, jest niezgodny z przepisami art. 64 ust. 1 i 2 w zw. z art. 2 i w zw. z art. 31 ust. 3 Konstytucji RP. W rozległym uzasadnieniu Rzecznik wskazał, że wskazany przepis ustawy nie tylko bezpośrednio godzi w zasadę proporcjonalności, lecz także arbitralnie ingeruje w sferę chronioną przez art. 64 ust. 1 Konstytucji RP praw majątkowych podmiotów, które naruszyły autorskie prawa majątkowe, a także w sposób nieznajdujący uzasadnienia w zasadach sprawiedliwości społecznej dyskryminuje te podmioty przez nierówne traktowanie ich w zakresie ochrony praw majątkowych przysługujących im na mocy art. 64 ust. 2 Konstytucji RP. W swym stanowisku Rzecznik przedstawił wyczerpująca argumentację przemawiająca za poglądem, który wielokrotnie były przedstawiany MKiDN przez środowiska użytkowników. Należy mieć zatem nadzieję, że Trybunał Konstytucyjny podzieli stanowisko użytkowników wspierane przez Rzecznika Praw Obywatelskich, penalny $\mathrm{w}$ istocie charakter polskiej regulacji jest bowiem ewidentny i stanowi skuteczny środek nacisku, w szczególności OZZ, pozwalający na narzucanie jednostronnie korzystnych umów z użytkownikami. 


\section{Nieprzygotowanie sądów do orzekania w sprawach z zakresu praw autorskich}

Jedna $\mathrm{z}$ wielu niepożądanych praktycznych konsekwencji wskazanych powyżej braków legislacyjnych oraz niespójności ustawy to rozliczne rozbieżności w orzecznictwie sądów powszechnych orzekających w sprawach z zakresu prawa autorskiego. Sytuacje takie obserwowane sa bowiem w wielu analogicznych, a czasami wręcz tożsamych stanach faktycznych. Prowadzi to do wysokiej niepewności prawnej, której negatywne konsekwencje najsilniej odczuwają podmioty prowadzące działalności opartą na eksploatacji utworów i przedmiotów praw pokrewnych. Wskazane niespójności orzecznicze związane sa głównie z sygnalizowanymi powyżej sporami między operatorami sieci kablowych a Stowarzyszeniem Filmowców Polskich. We wszczynanych lawinowo przez przedmiotowe Stowarzyszenie powództwach przeciwko operatorom powód domaga się jednocześnie zabezpieczenia roszczenia zakazowego. W świetle obowiąujących przepisów i istniejącego stanu faktycznego zabezpieczenie takie nie powinno jednak być przez sądy udzielane, nie tylko bowiem prowadzi to do zaspokojenia roszczenia przed rozpatrzeniem sprawy, ale $\mathrm{w}$ istocie skutkuje paraliżem całej działalności reemisyjnej, także w zakresie praw, które nie są zarządzane przez powoda ani objęte pozwem. Dodatkowo realizacja takiego zakazu w praktyce wiązałaby się z naruszeniem ustawowego obowiązku must carry wyrażonego w art. 43 ustawy o radiofonii i telewizji. W takim stanie rzeczy niestety tylko część sądów zauważa prawdziwe podłoże rzeczonych wniosków procesowych i przymusową sytuację, $\mathrm{w}$ jakiej znajdują się pozwani. Mimo identycznego z zasady stanu faktycznego część sądów dokonuje jednak diametralnie odmiennych ocen roszczeń. Szczególnie kontrowersyjne są przypadki, w których nawet sędziowie tego samego sądu, orzekający $\mathrm{w}$ innych wydziałach dokonują zupełnie rozbieżnych ocen w zasadzie identycznego stanu faktycznego i prawnego. Wskutek tego operatorzy w żaden sposób nie są w stanie przewidzieć rozstrzygnięcia sądu $\mathrm{w}$ tak istotnej dla nich kwestii. Sytuacja taka jest nie do przyjęcia. Przypisy Kodeksu postępowania cywilnego (art. 730 i n.) jednoznacznie określaja przesłanki udzielenia zabezpieczenia, a także zawierają normy prawne, których funkcją jest ochrona interesów podmiotów obowiązanych przed niewłaściwym korzystaniem z instytucji zabezpieczenia roszczeń przez wnioskodawców. Regulacje te, oprócz wymogu uprawdopodobnienia roszczenia oraz $-\mathrm{w}$ zw. $\mathrm{z}$ art. 80 ust. 1 ustawy, który ma w tym przypadku również zastosowanie - wykazania interesu prawnego, jednoznacznie wskazuja, że zabezpieczenie nie może obciążać obowiązanego ponad miarę (art. $730^{1}$ $\S 3$ k.p.c.). Niestety, mimo wskazywania tej okoliczności przez pozwanych, sądy niekiedy nie dostrzegaja konieczności zastosowania tego przepisu i uznaja wniosek o zabezpieczenie za zasadny. W konsekwencji stawia się użytkowników w sytuacji przymusowej, w której to muszą albo zawrzeć umowę na warunkach dowolnie podyktowanych przez OZZ (zob. wcześniejsze argumenty dotyczące braku realizacji obowiązku kontraktowania przez OZZ), albo de facto zrezygnować z prowadzenia działalności gospodarczej. Prowa- 
dzi to do zakłamania warunków panujących na polskim rynku medialnym, ze szkodą nie tylko dla bezpośrednio poszkodowanych przedsiębiorców, ale również konsumentów, którzy jako użytkownicy końcowi ponoszą dodatkowe obciążenia.

Obserwowane nieprawidłowości szeroko opisane w poprzednim akapicie stanowią także skutek braku znajomości przez sędziów orzekających realiów rynku medialnego oraz faktycznych skutków zabezpieczenia roszczenia zakazowego. Dodatkowo ujawnia się sygnalizowana na wstępie tendencja do traktowania ochrony praw autorskich jako dobra i celu samego w sobie. Sąy bowiem nierzadko nie badaja przyczyn określonego stanu, przez co sposób stosowania przez nie przepisów prawa autorskiego jest często nieprawidłowy. Rezultaty tego dla działalności przedsiębiorców - użytkowników praw autorskich i pokrewnych sa katastrofalne.

Rozwiązaniem takiego stanu rzeczy, oprócz wzmożonych szkoleń z zakresu praw własności intelektualnej, jest utworzenie wyspecjalizowanego sądu ds. własności intelektualnej, na kształt Sądu Ochrony Konkurencji i Konsumentów, który byłby władny rozstrzygać przedmiotowe spory. Idea ta popierana jest przez większość uczestników rynku i znajduje przychylność resortu kultury. Jednakże dotychczas koncepcja ta nie doczekała się choćby zarysu planów realizacji ani zawiązania koniecznej współpracy MKiDN z Ministrem Sprawiedliwości w tej sprawie.

\section{SKUTKI WSKAZANYCH PROBLEMÓW}

Opisane powyżej liczne nieprawidłowości systemu prawa autorskiego zarówno w zakresie aksjologicznym, ustawodawczym, jak i stosowania prawa przekładają się wprost na powstawanie nieakceptowalnie uciążliwych barier utrudniających prowadzenie działalności przez przedsiębiorców dostarczających usługi medialne na rzecz społeczeństwa informacyjnego. Wynika to w dużej mierze z faktu, że przy braku znajomości realiów rynkowych MKiDN i część opinii publicznej skupiają się przede wszystkim na ochronnej funkcji prawa autorskiego, zapominajac, że to prawo ma także za zadanie zapewniać możliwie szeroki dostęp społeczeństwa do kultury oraz wsparcie twórczości, przede wszystkim na gruncie finansowym. Realizacja obu wspomnianych celów nie tylko nie wyklucza się wzajemnie, ale realizacja pierwszego z nich, przy odpowiednim ukształtowaniu systemu prawa autorskiego, zapewni osiagnięcie drugiego. Dla wsparcia i promocji twórczości niewątpliwie niezbędna jest efektywna eksploatacja tworzonych dóbr, która zapewni twórcom należyte wynagrodzenie. Nie sposób nie odnotować także, że głównym źródłem owego wynagrodzenia są przedsiębiorcy - użytkownicy praw autorskich i praw pokrewnych. W przypadku, z którym mamy obecnie do czynienia, ustawodawca bezrefleksyjnie stawia bariery legislacyjne takiej efektywnej zależności. Dodatkowo z powodu zaniechania realizacji powierzonych określonym organom zadań publicznych istnieje przyzwolenie na ponoszenie przez przedsiębiorców 
zbędnych kosztów związanych z nadużyciami OZZ, co skutecznie zmniejsza popyt na dobra niematerialne, a w rezultacie także finansowanie sektora kreatywnego. Osiagany jest zatem skutek odwrotny do zamierzonego.

W nawiązaniu do wskazanych w punkcie II problemów należy zauważyć, że opisana praktyka niektórych sądów polegająca na udzielaniu w sprawach z powództw OZZ zabezpieczeń w postaci zakazu reemisji, będąc środkiem rażąco nieadekwatnym, skutkuje realną koniecznością zaprzestania prowadzenia działalności gospodarczej przez pozwane podmioty. Prowadzona przez tych użytkowników praw autorskich i praw pokrewnych działalność polega implicite na rozpowszechnianiu w całości i bez zmian programu organizacji radiowej lub telewizyjnej oraz równoczesnego i integralnego przekazywania tego programu do powszechnego odbioru. W przypadku reemitowania utworów audiowizualnych, stanowiących dużą część rozpowszechnianych treści, nałożenie zakazu reemisji oznacza także zaprzestanie uzyskiwania przez pozwanego jakiegokolwiek zysku umożliwiajacego spłatę zobowiązań, a zaprzestanie działalności uderza rzecz jasna w równie dużym stopniu w odbiorców końcowych usług - abonentów pozwanego.

Rozliczne przeszkody, utrudnienia i zagrożenia związane z podejmowaniem działalności gospodarczej chociażby w obszarze reemisji skłaniają część przedsiębiorców do rezygnacji z tak ryzykownej formy zarobkowania i poddania się procesom konsolidacyjnym z nadzieją, że więksi przedsiębiorcy będą w stanie skuteczniej podjąć nierówną walkę z głównymi beneficjentami niesprawnego systemu prawa autorskiego - organizacjami zbiorowego zarządzania prawami autorskimi lub prawami pokrewnymi.

Efektem przedstawionych w niniejszym artykule problemów jest nierównowaga na rynku obrotu prawami autorskimi i pokrewnymi. Dodatkowo wskazać należy, że podejmowane na przestrzeni ostatnich lat prace nad zmianami ustawy spowodowane były w większości przymusowymi czynnikami zewnętrznymi, jak wyrok Trybunału Konstytucyjnego czy konieczność implementacji norm unijnych i naciski Komisji Europejskiej. Ustawodawca popadł w swoista inercję, nie dostrzegając narastających wad systemowych i nie reagując na rozliczne apele o poprawę kondycji regulacji prawnoautorskich. Zachowanie takie jest całkowicie niezrozumiałe $\mathrm{w}$ dobie społeczeństwa informacyjnego, w którym chociażby Agenda Cyfrowa Unii Europejskiej stanowi główny, acz niejedyny przykład nacisku międzynarodowej społeczności na kształcenie obywateli pod katem dostępu do nowoczesnych technologii, a co za tym idzie - dóbr kultury i dziedzictwa narodowego, które zawierają się w przedmiotach ochrony prawnoautorskiej. Chociażby z tego względu, mając na uwadze całokształt więzi opartych na prawie autorskim i dobrostan uprawnionych i odbiorców kultury, zachowanie równowagi pomiędzy wszystkimi grupami interesów jest szczególnie istotne. Obecny kształt systemu prawa autorskiego sprawia, że największymi jego beneficjentami, przede wszystkim w rozumieniu finansowym, są OZZ, które pełnić powinny funkcje pomocnicze i w istocie usługowe. Bezsprzecznie zatem punkt ciężkości w obecnie obowiązującej ustawie został rozłożony nieprawidłowo. 


\section{PODSUMOWANIE - POSTULATY ZMIAN}

Dwudziestolecie obecnej ustawy to znakomita okazja do podsumowań i refleksji. Te jednak, wobec wielości i ciężaru gatunkowego problemów, nie napawają optymizmem. Cieszą próby wysunięcia tematyki prawnoautorskiej na czoło debaty publicznej. Nadzieją na szybkie zmiany są organizowane przez MKiDN spotkania w ramach Forum Prawa Autorskiego lub konferencje naukowe podejmujące tę trudną tematykę. Zasygnalizowane powyżej pokrótce problemy gnębiące obecnie system prawa autorskiego wymagają radykalnych i możliwie szybkich kroków legislacyjnych i edukacyjnych, gdyż status quo zagraża zarówno kondycji twórczości, jak i jej owocnemu oraz możliwie szerokiemu wykorzystywaniu, uderzając przede wszystkim w społeczeństwo oraz samych uprawnionych.

Wskazać zatem należy na najważniejsze postulaty wysuwane przez użytkowników praw autorskich i praw pokrewnych, które stanowia próbę ogólnego podsumowania refleksji dotyczącej aktualnego stanu systemu prawa autorskiego:

1) zmiana sposobu myślenia o prawie autorskim wyłącznie przez pryzmat środków ochrony praw wyłącznych i stawiania w centrum tylko interesów twórców z pominięciem użytkowników;

2) wprowadzenie przejrzystości zasad w wyznaczaniu stawek wynagrodzeń przysługujących twórcom i innym uprawnionym i reforma procedury zatwierdzania tabel oraz rozstrzygania sporów związanych ze zbiorowym zarządem, tak aby procedury te były efektywne, a przy tym zapewniały równe pozycje zainteresowanych stron i nie powodowały po stronie wnioskodawcy nadmiernych i bezzwrotnych kosztów;

3) wzmocnienie nadzoru Ministra Kultury i Dziedzictwa Narodowego nad funkcjonowaniem OZZ oraz wprowadzenie realnych sankcji za nieprawidłowe wykonywanie zbiorowego zarządu przez te organizacje;

4) dokonanie przeglądu i analizy udzielonych OZZ zezwoleń oraz wprowadzenie do nich niezbędnych zmian;

5) wprowadzenie jawności w zakresie zarządzania finansami OZZ oraz przepływów finansowych pomiędzy tymi organizacjami a uprawnionymi;

6) sfinalizowanie implementacji właściwych uregulowań unijnych, zapewniających:

- pewność nabycia, w drodze umów z OZZ, wszystkich praw niezbędnych do rozprowadzania programów, w tym w szczególności do utworów audiowizualnych oraz wideogramów,

- możliwość uzyskania zezwolenia na reemisję bezpośrednio od organizacji radiowej lub telewizyjnej, dysponującej odpowiednimi prawami,

- przystapienie stron do negocjacji dotyczących zezwoleń na reemisję i prowadzenia tych negocjacji w dobrej wierze wraz z wykluczeniem możliwości utrudniania lub uniemożliwiania ich prowadzenia,

- wprowadzenie modelu odpowiedzialności odszkodowawczej opartego na obiektywnym kryterium rekompensaty, a nie swoistej kary cywilnej;

7) utworzenie wyspecjalizowanego i należycie przygotowanego sądownictwa ds. własności intelektualnej. 
W debacie dotyczącej praw własności intelektualnej podnosi się coraz częściej postulat ustanowienia regulatora praw autorskich, czyli organu na kształt urzędu ochrony praw własności intelektualnej. Argumentem przemawiajacym za takim rozwiązaniem jest przede wszystkim fakt, że w przypadku praw autorskich mamy do czynienia $\mathrm{z}$ regulowanym sektorem o istotnym interesie publicznym (dostęp do dóbr kultury i promowanie społeczeństwa informacyjnego). Można także zaryzykować stwierdzenie, że wyspecjalizowany organ regulator ze znajomością przedmiotu sprawy oraz przygotowaniem teoretyczno-praktycznym w znacznie większym stopniu mógłby uwzględniać specyfikę rynku praw własności intelektualnej. Rzecz jasna nawet w przypadku rozważenia takiej modyfikacji systemu prawa autorskiego należy uwzględnić funkcjonowanie właściwych sądów powszechnych, jako instancji odwoławczych, których wyspecjalizowanie, jak wskazano wyżej, jest więcej niż konieczne.

Wszystkie wskazane działania - choć stanowią wyłącznie wycinek całej problematyki związanej z systemem prawa autorskiego - powinny przebiegać w duchu dążenia do stworzenia równowagi i poszanowania interesów zarówno podmiotów uprawnionych, jak i użytkowników. Funkcjonowanie konkurencyjnego, niedyskryminującego i partnerskiego systemu jest szansą zarówno dla polskiej kultury, jak i dla rozwoju społeczeństwa oraz przedsiębiorczości, które to stanowią filary prawa autorskiego.

Jerzy Straszewski

Prezes Polskiej Izby Komunikacji Elektronicznej

\section{COPYRIGHT LAW IN POLAND AT THE AGE OF AN INFORMATION SOCIETY - A CRITICAL VOICE OF COPYRIGHT USERS}

Summary

The article contains a critical summary of the twentieth anniversary of the Act on Copyright and Related Rights being in force, and focuses on the issue of the position of copyright users in today's copyright-related market. The main problems of the functioning of copyright law in Poland are identified and the ineffective enforcement of law by administrative authorities presented. The non-existence of an efficient collective management system is also raised, as well as the resulting immense inequality of copyright market participants. Attention has been drawn to the increasing difficulties and barriers to conducting businesses that depend on copyright and relative rights use, to obsolete regulation, non-consistent judicial rulings and repressive liability principles imposed. The author then makes some recommendations, mostly legislative, that could provide for some adjustments to the benefit of all copyright-market participants. 
